DOI: https://doi.org/10.47405/mjssh.v5i12.597

\begin{tabular}{|c|c|}
\hline The & Malaysian Journal of Social Sciences and Humanities (MJSSH) \\
\hline Malaysian Journal of & Volume 5, Issue 12, December 2020 \\
\hline (MJ-ssH) & e-ISSN : 2504-8562 \\
\hline & $\begin{array}{l}\text { Journal home page: } \\
\text { www.msocialsciences.com }\end{array}$ \\
\hline
\end{tabular}

\title{
Analisa Konsep Pertahanan Menyeluruh (HANRUH) dalam Program Latihan Khidmat Negara (PLKN)
}

\author{
Muhamad Ridzuan Bin Hashim1, Nazariah Osman1, Mohamad Faisol Keling1 \\ ${ }^{1}$ College of Law, Government and International Studies, Universiti Utara Malaysia (UUM) \\ Correspondence: Muhamad Ridzuan Bin Hashim (idzuanhshm@yahoo.com)
}

\begin{abstract}
Abstrak
Konsep Pertahanan Menyeluruh adalah berkait dengan usaha yang total dan bersepadu yang dilaksanakan oleh kerajaan, agensi bukan kerajaan, sektor swasta dan rakyat jelata dalam mempertahankan negara. Pemeliharaan keutuhan dan kedaulatan Malaysia memerlukan komitmen semua lapisan rakyat, dan tidak hanya dijalankan oleh angkatan tentera. Secara logikal tugas mempertahankan negara merupakan tanggungjawab pasukan keselamatan dan kewajipan untuk memastikan bahawa pasukan berkenaan mampu menghadapi cabaran adalah tanggungjawab nasional. Oleh itu, rakyat Malaysia perlu dipupuk semangat cinta akan negara atau patriotisme dan perlu mendedahkan semangat untuk mempertahankan negara dalam apa jua keadaan sekali pun. Latihan khidmat negara (National Service) dilihat sebagai salah satu pendekatan bagi sesebuah negara untuk mendekatkan rakyat kepada konsep ini. Oleh itu, kajian ini akan melihat konsep pertahanan menyeluruh dalam latihan khidmat negara yang telah dijalankan oleh negara Malaysia iaitu Program Latihan Khidmat Negara (PLKN).
\end{abstract}

Kata kunci: HANRUH, Pertahanan Menyeluruh, ATM, PLKN

\section{Analysis of the Concept of Total Defense (HANRUH) in the National Service Training Program (PLKN)}

\begin{abstract}
The concept of Total Defense is related to the total efforts undertaken by the government, nongovernmental agencies, the private sector and the people in defending the country. Preserving the integrity and sovereignty of Malaysia requires the commitment of all the people, and not just carried out by the armed forces. Logically the task of defending the country is the responsibility of the security forces like ATM, and the duty to ensure that the forces are able to face challenges is a national responsibility. Therefore, Malaysians need to be nurtured in the spirit of love for the country or patriotism and need to express the spirit to defend the country in any situation. National service training is seen as one of the approaches for a country to bring the people closer to this concept. Therefore, this study will look at the concept of total defense in national service training that has been conducted by Malaysia, namely the National Service Training Program (PLKN)
\end{abstract}

Keywords: HANRUH, Total Defense, ATM, PLKN 


\section{Pengenalan}

Konsep Pertahanan Menyeluruh (HANRUH) berkait rapat dengan usaha menyeluruh dan bersepadu yang dilaksanakan oleh kerajaan, agensi bukan kerajaan, sektor swasta dan rakyat jelata dalam mempertahankan kedaulatan negara ${ }^{1}$. Sungguhpun tugas mempertahankan negara merupakan tanggungjawab pasukan keselamatan, kewajipan untuk memastikan pasukan berkenaan mampu menghadapi cabaran dan ancaman adalah tanggungjawab nasional ${ }^{2}$.

\section{Definisi Konsep Pertahanan Menyeluruh adalah Pertahanan Awam (Civilian Defense) sebagai satu angkatan yang terdiri dari masyarakat awam dalam tujuan mempertahankan negara. Ia hendaklah terkandung dalam polisi kerajaan dan melibatkan masyarakat secara keseluruhan. Ia bertujuan bukan sahaja untuk mengubah pendirian lawan, tetapi juga dibentuk bagi menjadi tiada kemungkinan untuk mereka mencapai tujuannya. ${ }^{3}$}

Oleh hal yang demikian, keadaan ini terus menjadikan keselamatan negara sebagai tanggungjawab bersama, tidak mengambil kira status bangsa ${ }^{4}$, agama, perbezaan politik mahupun kelas pekerjaan 5 . HANRUH bukanlah satu konsep pertahanan baharu. Konsep ini telah digunakan sejak zaman Perang Dingin lagi atau Cold War oleh beberapa buah negara seperti Denmark, Finland, Sweden, Switzerland dan Singapura ${ }^{6}$ (Koleksi Arkib Ucapan, 2007). Terdapat beberapa ciri persamaan HANRUH yang diguna pakai oleh beberapa buah negara di mana objektif utama HANRUH ialah untuk menghalang peperangan, mempertahankan negara dan melindungi masyarakat awam ${ }^{7}$. Selain itu, pertahanan menyeluruh perlu dikekalkan dengan kesiapsiagaan yang berterusan serta mempunyai keupayaan ${ }^{8}$ untuk membendung sebarang ancaman dan mewujudkan pertahanan untuk menyelaraskan usaha dan tindakan yang melibatkan sektor awam dan swasta khususnya dalam penggunaan sumber dan aset dalam mempertahankan negara9. Secara umumnya, HANRUH mengguna pakai lima komponen aspek pertahanan iaitu:

$\begin{aligned} \text { i. } & \text { Military Defence } \\ \text { ii. } & \text { Civil Defence } \\ \text { iii. } & \text { Economic Defence } \\ \text { iv. } & \text { Social Defence } \\ \text { v. } & \text { Psychological Defence. }\end{aligned}$

\footnotetext{
${ }^{1}$ Teks Rasmi Titah Duli Yang Maha Mulia Paduka Seri Sultan Perak Sultan Nazrin Muizzuddin Shah. Upacara Perbarisan Pentauliahan Pega wai Kadet Palapes Universiti Awam Ketiga Puluh Lima. 20 Ogos 2016. Universiti Malaya, Kuala Lumpur. hlm 1-8

${ }^{2}$ Teks Rasmi Perutusan Hari Tentera Darat Ke-85 Oleh Panglima Tentera Darat Pada 1 Mac 2018. Hlm $1-8$

${ }^{3}$ Adam Roberts (ed), The Strategy ofCivilian Defence, Faber a nd FaberLtd, London, 1967, him. 11.

${ }^{4}$ Alis Puteh. Language \& nation building. Petaling Ja ya: SIRD. 2006.hlm 13-42

${ }^{5}$ Wan Kamarudin Wan Hamat (2002). Khidmat Bakti Ke Arah Mesra Rakyat. Patriot. Bil 2. 2002.hlm 89

${ }^{6}$ Teks Rasmi Ucapan Jeneral Tan Sri Dato' Sri Abdul Aziz Bin Hj Zainal, Panglima Angkatan Tentera Sempena Majlis Pelancaran Sambutan 25 Tahun Pernama Di Auditorium Kementerian Pertahanan Pada 20 Julai2007.hlm 1-5

${ }^{7}$ Teks Rasmi Perutusan Hari Tentera Darat Ke-85 Oleh Panglima Tentera Darat Pada 1 Mac 2018. Hlm 1-8. Lihat juga Vishalache Balakrishnan (2013). Penilaian PLKN Dari Perspektif Pelatih: Satu Kajian Kes (Evaluation Of The National Service Training Program From The Perspective Of A Trainee: A Ca se Study). Asia Pa cific Journal of Educators and Education. Vol. 28. hlm 69-80.

${ }^{8}$ Teks Rasmi Ucapan Jeneral Tan Sri Da to' Sri Abdul Aziz Bin Hj Zainal, Panglima Angkatan Tentera Sempena Majlis Pelancaran Sambutan 25 Tahun Pernama Di Auditorium Kementerian Pertahanan Pada 20 Julai2007.hlm 1-5

${ }^{9}$ Teks Rasmi Titah Duli Yang Maha Mulia Paduka Seri Sultan Perak Sultan Nazrin Muizzuddin Shah. Upacar Perbarisan Pentauliahan Pegawai Kadet Pa lapes Universiti Awam Ketiga Puluh Lima. 20 Ogos 2016. Universiti Malaya, Kuala Lumpur. hlm 1-8
} 
Rajah: Lima komponen pertahanan

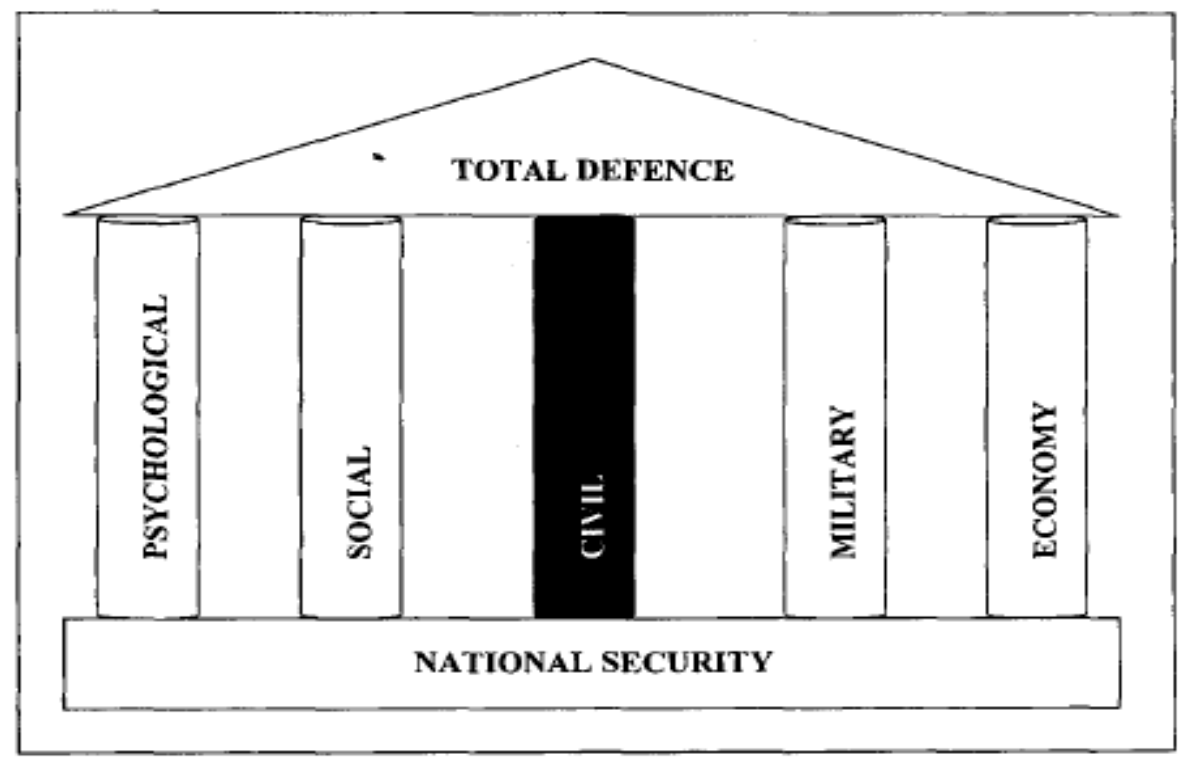

FIGURE 2.1 Conceptual Framework of Total Defence Components to Address Comprehensive Security

Sumber: Yeow (2007)

Dalam konteks pertahanan di Malaysia, HANRUH merupakan strategi ketiga bagi Dasar Pertahanan Negara, selain daripada Strategi Deterrence dan Forward Defence ${ }^{I 0}$. Seperti yang sedia maklum, Dasar Pertahanan Negara (DPN) adalah berteraskan pembangunan keupayaan atau "capability driven" dan bukanlah berasaskan sebarang bentuk ancaman ${ }^{11}$. Disebabkan negara tidak dijangka akan mengalami ancaman konvensional pada masa hadapan, oleh hal yang demikian, strategi HANRUH diletakkan dalam DPN ${ }^{12}$ untuk menggembleng keseluruhan sumber untuk mempertahankan negara dan strategi Deterrence dan Forward Defence berteraskan pembangunan keupayaan bagi menjaga kedaulatan dan kepentingan negara ${ }^{13}$. Jika dilihat dari aspek komponen pertahanan menyeluruh, untuk menjayakan setiap satu komponen memerlukan usaha sama, bukan sahaja daripada kementerian, jabatan, badan berkanun, badan bukan kerajaan, syarikat kerajaan dan sektor swasta, malahan ia memerlukan lebih daripada itu di mana penglibatan orang awam juga penting bagi menjunjung konsep pertahanan menyeluruh ini ${ }^{14}$. Disebabkan ini, kerajaan telah menubuhkan pelbagai angkatan sukarela bukan sahaja di Institut Pengajian Tinggi (IPT) Negara tetapi di setiap lapisan masyarakat seperti Jawatan Kuasa Kerja Kampung (JKKK), Ikatan Sukarelawan Malaysia (RELA), Angkatan Pertahanan Awam (APM), Askar Wataniah (AW), Polis Bantuan dan Sukarelawan Polis ${ }^{15}$. Menteri Pertahanan,

\footnotetext{
${ }^{10}$ Teks Rasmi Perutusan Hari Ulang Tahun Tentera Darat Ke-79 .Jeneral Datuk Haji Zulkifli Haji Zainal Abidin, Panglima Tentera Darat Pada 1 Mac 2012.hlm 1-12

${ }^{11}$ Mohd Nooraimy Bin Musa (2009). Dasar Pertahanan Negara - Menganalisis Kemampuan Angkatan Tentera Malaysia Mendukung Dasar Tersebut Pada Era Globalisasi. Universiti Ma laya: Fakulti Sastera Dan Sa ins Sosia 1. Hlm 29. Lihat juga Mohd Nazeri Bin Noor (2008). Dasar Pertahanan Nega ra Ma laysia: Satu Analisa Terhadap Persenjataan. Tesis.Universiti Malaya: Fakulti Sastera Dan Sains Sosial. hlm 3740

${ }^{12}$ Mohd Nazeri Bin Noor (2008). Dasar Pertahanan Negara Malaysia: Satu Analisa Terhadap Persenjataan. Tesis.Universiti Malaya: Fakulti Sa stera Dan Sains Sosial. hlm 37-40

${ }^{13}$ Teks Rasmi Perutusan Hari Tentera Darat Ke-85 Oleh Panglima Tentera Darat Pada 1 Mac 2018. Hlm $1-8$

${ }^{14}$ Mohd Nooraimy Bin Musa (2009). Dasar Pertahanan Negara - Mengana lisis Kemampuan Angkatan Tentera Malaysia Mendukung Dasar Tersebut Pada Era Globalisasi. Universiti Malaya: Fakulti Sastera Dan Sa ins Sosial. Hlm 29. Lihat juga www.pmo.gov.my

${ }^{15}$ Education Ma laysia for student. (2014). 4 national service (NS/PLKN) training modules. Retrieve on May 17, 2019 from https://education.malaysia-students.com/2014/07/4-national-service-ns-plkntraining.html. Lihat juga . Siti Raba'ah Hamzah, Turiman Suandi \& Siti Nur Syuhada Musa (2019). Profil Kesuka rela wanan Belia Ma laysia. Malaysian Joumal of Youth Studies Vol 19.Jun hlm 18-37. Lihat juga
} 
Dato' Seri Dr Ahmad Zahid Hamidi bertempat di Padang Kawad KEMENTAH pada 15 Dis 2009, mengungkapkan:

\begin{abstract}
"Segala bentuk pentadbiran dan latihan diuruskan oleh Bahagian Pasukan Simpanan Tentera Darat (BPSTD) dan Rejimen 502 Askar Wataniah. Penyertaan staf awam akan diperluaskan secara berperingkat kepada agensi-agensi lain di bawah kementerian ini dan secara tidak langsung dapat menyahut dan menghayati konsep 1Malaysia dan Pertahanan Menyeluruh (HANRUH) dalam memberi sumbangan sebagai barisan kedua kepada pertahanan negara" 16
\end{abstract}

\title{
Konsep Pertahanan Menyeluruh ( HANRUH) dan Program PLKN
}

Menurut pendekatan realisme, keselamatan negara mempertimbangkan negara sebagai aktor utama dalam sistem antarabangsa. Konsep keselamatan ini adalah mengenai memperkukuhkan agenda negara bangsa dalam membentuk dasar keselamatan negara, memperkukuhkan sumber ekonomi dan juga aspek bukan ketenteraan yang boleh menyumbang kepada kelangsungan fungsi negara bangsa ${ }^{17}$. Konsep keselamatan negara menjurus kepada situasi kebebasan dan keamanan dari segala ancaman terhadap tunjang-tunjang negara yang didokong oleh kerajaan. Konteks keselamatan mudah difahami dengan perlindungan umum dari kerajaan kepada sesebuah negara dan dikawal oleh pasukan keselamatan di Malaysia terdiri daripada pasukan Polis Diraja Malaysia (PDRM), polis bantuan, Angkatan Tentera Malaysia (ATM) dan Agensi Penguatkuasaan Maritim. Keamanan dan kedaulatan negara yang stabil akan menjamin kepada tahap keselamatan negara yang baik ${ }^{18}$. Menurut Tan Sri Dato’ Muhyiddin Mohd. Yassin, Menteri Dalam Negeri (2019):-

\begin{abstract}
"Dasar Keselamatan dan Ketenteraman Awam (DKKA) meliputi teras dan strategi yang merupakan sebuah dasar yang bersifat holistik dan menjadi panduan dalam usaha kita menjamin keselamatan dan ketenteraman awam. Dalam era globalisasi yang semakin mencabar dan perkembangan teknologi baharu berasaskan Revolusi Industri 4.0, risiko dan ancaman terhadap keselamatan negara kini menjadi semakin kompleks dan merentasi sempadan. Senario ini memerlukan penglibatan semua pihak bersama-sama kerajaan untuk menghadapi dan menangani isu serta cabaran keselamatan semasa. Hubungan kerjasama erat di antara kerajaan dan masyarakat amat diperlukan selaras dengan tema Dasar Keselamatan dan Ketenteraman Awam (DKKA) iaitu "Keselamatan dan Ketenteraman Awam: Tanggungjawab Bersama". ${ }^{19}$
\end{abstract}

Dalam mengekalkan dan menjaga keselamatan negara terdapat beberapa aspek yang perlu dititik beratkan dan diambil kira ialah mempertahankan agenda negara bangsa dalam membentuk dasar pertahanan negara, persediaan lengkap aset pejuang sebagai alat memelihara keselamatan memerlukan kestabilan dalam ekonomi demi kelangsungan fungsi negara bangsa demi menjamin keselamatan

kesan PLKN di IPTA Siti Raba'ah Hamzah, Turiman Suandi \& Ismi Arif Isma il (2019).Penga ruh Aktiviti Sukarela Terhadap Tingkah Laku Sedentari Belia Institusi Pengajian Tinggi di Malaysia. . Malaysian Journal Of Youth Studies. Edisi Kha s Yours'18 Agenda Sosial Vol 1. Hlm 50-68

${ }^{16}$ Syuhaimi Saad (2010). Kumpulan Kedua AW Kementerian Pertahanan dilancarkan. BTDM. Bil. 106. Januari.2010.hlm 5

${ }^{17}$ Wan Kamarudin Wan Hamat (2002). Hubungan Tentera-Awam Kearah Pengukuhan Keselamatan Negara.Patriot. Bil 2.2002.hlm 29

${ }^{18}$ Teks Rasmi Perintah Ulung Panglima Tentera Darat Ke-25, Jeneral Datuk Raja Mohamed Affandi Raja Mohamed Noor Panglima Tentera Darat. 19 Jun 2013 hlm 1-8. Lihat juga B. Jalal (2016). Hubungan Tentera Dan Masyarakat: Pandangan Rakyat Terhadap Peranan Angkatan Tentera Malaysia (Military and Community Relations: People's view on the role of the Armed Forces). Jumal Jabatan Kenegaraan, Kepemimpinan dan Ketamadunan, Universiti Pertahanan Nasional. Vol.4. Bil 1. hlm 19-30

${ }^{19}$ Perutusan YB Tan Sri Dato' Hj. Muhyiddin Bin Hj. Mohd. Yassin, Menteri Dalam Negeri,Tan Sri Dato' Hj. Muhyidd in Bin Hj. Mohd. Yassin. Dasar Keselamatan dan Ketenteraman Awam. Kementerian Dalam Negeri.2019.hlm iv 
negara perlu diambil kira ${ }^{20}$. Sejarah telah menunjukkan bahawa Malaysia telah berdepan dengan pelbagai ancaman keselamatan, ancaman yang mencabar kedaulatan Malaysia yang berprinsipkan raja berperlembagaan termasuklah keselamatan dan ketenteraman awam ${ }^{21}$. Pada masa kini, ancaman terhadap keselamatan bukan lagi tertumpu kepada penjajahan antara negara, malah revolusi turut berlaku daripada perspektif ancaman keselamatan yang lebih kompleks dan mampu menghuruharakan kedaulatan negara ${ }^{22}$.

Keselamatan negara dipantau dan dijaga oleh pihak bertanggungjawab di Malaysia dipanggil sebagai Majlis Keselamatan Negara (MKN). MKN telah ditubuhkan secara rasmi pada 7 Julai 1971 oleh Perdana Menteri Malaysia yang keempat iaitu Tun Dr. Mahathir. MKN telah ditubuhkan selepas Majlis Gerakan Negara (MAGERAN) dibubarkan pada 1971. Tujuan asal penubuhan MAGERAN adalah demi menjamin keamanan dan keselamatan negara selepas berlakunya peristiwa 13 Mei $1969^{23}$. Perdana Menteri merangkap sebagai Pengarah MAGERAN bertanggungjawab penuh dalam mengembalikan keamanan dan kestabilan keselamatan kepada negara. Selepas bubarnya MAGERAN ini, keselamatan negara masih goyah. Negara masih menerima ancaman daripada pihak komunis dan maka dengan itu, tertubuhnya MKN untuk menjaga dan mengelakkan insiden-insiden yang boleh menggugat keselamatan negara berlaku. Dasar berkaitan keselamatan negara yang digubal oleh kerajaan adalah di bawah penguasaan $\mathrm{MKN}$, termasuklah gerakan keselamatan negara, keamanan awam dan merangkumi segala aspek berkaitan keselamatan. MKN merupakan badan utama dalam membantu Majlis Tindakan Negara berkaitan keselamatan ${ }^{24}$.

Kerajaan telah memperkenalkan dasar utama dalam menjamin keselamatan negara iaitu Dasar Keselamatan Negara atau dikenali sebagai DKN. Dasar Keselamatan Negara diperkenalkan di bawah Akta Keselamatan Negara 2016 (AKTA 776). Dasar Keselamatan Negara ialah sumber rujukan utama diguna pakai oleh kementerian-kementerian di Malaysia dan di dokumentasi sebagai persiapan dan panduan dalam menghadapi sebarang bentuk ancaman. Dasar Keselamatan Negara menjadi tunjang utama dalam mengekalkan keamanan dan perpaduan kaum ${ }^{25}$. Strategi utama Dasar Keselamatan Negara diwujudkan adalah untuk memastikan nilai-nilai teras negara dapatkan dikekalkan dan membentuk Malaysia bebas dari segala ancaman yang mampu memporak-perandakan rakyat bahkan menggoyahkan keselamatan negara ${ }^{26}$. Dasar Pertahanan Negara mempunyai sembilan teras utama dan sembilan belas strategi demi menjamin keutuhan keselamatan negara. Sembilan teras utama ini menjadi perisai kepada kerajaan untuk diaplikasikan sebagai rujukan dan panduan. Kedudukan

\footnotetext{
${ }^{20}$ Mohd Nazeri Bin Noor (2008). Dasar Pertahanan Negara Malaysia: Satu Analisa Terhadap Persenjataan. Tesis.Universiti Malaya: Fakulti Sastera Dan Sains Sosial. hlm 37-40

${ }^{21}$ Teks Rasmi Perutusan Hari Tentera Darat Ke-85 Oleh Panglima Tentera Darat Pada 1 Mac 2018. Hlm 1-8 lihat juga Teks Rasmi Ucapan Jeneral Tan Sri Dato' Sri Abdul Aziz Bin Hj Zainal, Panglima Angkatan Tentera Sempena Majlis Pelancaran Sambutan 25 Tahun Pemama Di Auditorium Kementerian Pertahanan Pada 20 Julai 2007.hlm 1-5

${ }^{22}$ Mohd Nooraimy Bin Musa (2009). Dasar Pertahanan Negara - Menganalisis Kemampuan Angkatan Tentera Malaysia Mendukung Dasar Tersebut Pada Era Globalisasi. Universiti Malaya: Fakulti Sastera Dan Sa ins Sosial. Hlm 29. Lihat juga

${ }^{23}$ Teks Rasmi Perintah Ulung Panglima Tentera Darat Ke-25, Jeneral Datuk Raja Mohamed Affandi Raja Mohamed Noor Panglima Tentera Darat. 19 Jun 2013.hlm 1-8

${ }^{24}$ Mohd Nooraimy Bin Musa (2009). Dasar Pertahanan Negara - Menganalisis Kemampuan Angkatan Tentera Malaysia Mendukung Dasar Tersebut Pada Era Globalisasi. Universiti Malaya: Fakulti Sastera Dan Sa ins Sosial. Hlm 29.

${ }^{25}$ Abdul Rahman Embong. (2001). Negara bangsa: Proses dan perbahasan. Bangi: Penerbit Universiti Kebangsaan Malaysia hlm 6-25. Lihat juga Yasmin Binti Yaccob \& Mohd Ibrani Shahrimin Adam Assim (2018). Kesepaduan Sosial Mela lui Program Anugerah Remaja Perdana Rakan Muda. Malaysian Joumal Of Youth Studies Vol 18. Jun. hlm 219-242

${ }^{26}$ Teks Rasmi Ucapan Jeneral Tan Sri Dato' Sri Abdul Aziz Bin Hj Zainal, Panglima Angkatan Tentera Sempena Majlis Pelancaran Sambutan 25 Tahun Pernama Di Auditorium Kementerian Pertahanan Pada 20 Julai2007.hlm 1-5
} 
Semenanjung Malaysia dan Sabah, Sarawak yang terpisah memerlukan kawalan keselamatan yang tinggi kerana ancaman daripada pihak luar mampu menggoyahkan kawalan keselamatan ${ }^{27}$.

Di samping itu, aktor penting dalam menjaga keselamatan negara bukan sahaja kerajaan, tetapi rakyat juga perlu berganding bahu bersama-sama bekerjasama dengan kerajaan untuk menjaga keamanan dan mengekalkan keselamatan negara yang ada ${ }^{28}$. Dalam memastikan kelangsungan Malaysia selepas kemerdekaan, negara mempraktikkan konsep demokrasi berparlimen dan Raja Berperlembagaan. Antara kerjasama strategik yang dijalankan oleh Malaysia ialah ASEAN Regional Forum (ARF), ASEAN Defence Ministerial Meeting (ADMM), Five Power Defence Arrangement (FPDA) dan sebagainya bagi melindungi kepentingan negara. Dalam masa itu juga, demi menjaga keselamatan, satu kerjasama strategik antarabangsa bersama beberapa buah negara dijalinkan bertujuan untuk menjaga keselamatan serantau sekali gus menjamin keselamatan negara ${ }^{29}$.

\section{Analisa Perlaksanaan Khidmat Negara (NationalService) di Luar Negara}

Konsep perlaksanaan latihan kerahan tenaga di setiap negara adalah berbeza-beza. Namun begitu, latihan kerahan tenaga di Malaysia mempunyai beberapa ciri persamaan perlaksanaan dengan sistem perlaksanaan kerahan tenaga di Britain dan Australia. Antara persamaan ciri dan perlaksanaan latihan kerahan tenaga di Malaysia dengan Britain dan Australia ialah latihan kerahan tenaga di ketiga-tiga buah negara ini mensyaratkan bahawa remaja yang berumur 18 tahun dan ke atas hendaklah mendaftarkan diri dan menyertai latihan kerahan tenaga. Pelatih remaja yang menyertai latihan kerahan tenaga hendaklah mempunyai tubuh badan dan akal fikiran yang sihat. Di Malaysia, pihak kerajaan akan memilih remaja yang baru sahaja menamatkan zaman persekolahan di sekolah menengah untuk menyertai latihan ini, dan pelatih hendaklah menyertai latihan kerahan tenaga walaupun mereka tidak suka. Pengecualian penyertaan hanya akan diberikan atas beberapa sebab seperti pelatih mempunyai penyakit yang berisiko membahayakan diri sendiri dan orang lain, sudah berkahwin, pelatih mempunyai komitmen lain seperti sedang menyambung pengajian, buta dan sebagainya ${ }^{30}$. Jika di Britain, pelatih diberi pengecualian untuk menyertai latihan kerahan tenaga jika mereka sedang bekerja di jabatan kerajaan, perlombongan arang batu, tentera, peniaga atau pertanian. Latihan kerahan tenaga ini mewajibkan penyertaan ke atas lelaki dan wanita namun di Britain dan Australia wanita tidak dibenarkan untuk menyertai latihan ini.

Seterusnya, persamaan ciri perlaksanaan latihan kerahan tenaga di ketiga-tiga buah negara ini adalah latihan yang diberikan adalah berkonsepkan ketenteraan. Latihan seperti ini dipilih kerana mereka percaya latihan ini dapat melatih kekuatan mental dan fizikal dalam diri setiap pelatih ${ }^{31}$. Hal ini demikian kerana pelatih yang menyertai latihan kerahan tenaga ini akan menjalani latihan separa ketenteraan $^{32}$. Mereka akan menjalani latihan separa ketenteraan seperti berkawad yang bertujuan untuk melatih sikap pentingkan disiplin dalam diri ${ }^{33}$ pelatih, latihan menggunakan senjata dan beberapa aktiviti lasak yang lainnya. Latihan-latihan yang dijalankan bertujuan untuk melatih mental

\footnotetext{
${ }^{27}$ Mohd Nooraimy Bin Musa (2009). Dasar Pertahanan Negara - Mengana lisis Kemampuan Angkatan Tentera Malaysia Mendukung Dasar Tersebut Pada Era Globalisasi. Universiti Malaya: Fakulti Sastera Dan Sa ins Sosial. Hlm 29. Lihat juga

${ }^{28}$ Projek Jiwa Murni, Akrabkan kerajaan, Tentera dan Rakyat. Patriot. Bil 1.2000.hlm 8

${ }^{29}$ Wan Kamarudin Wan Hamat (2002). Khidmat Bakti Ke Arah Mesra Rakyat. Patriot. Bil 2. 2002.hlm 8 9

${ }^{30}$ Abdul Rahman Abdul Aziz, Mohd. Sobhi Ishak, Malike Brahim \& Mohd. Ainuddin Iskandar Lee Abdullah. (2004). Penyelidikan program khidmat negara dari aspek gagasan kenegaraan. Laporan Penyelidikan. Sintok: Pusat Penyelidikan dan Perundingan, Universiti Utara Malaysia.

${ }^{31}$ Jaffry Zakaria, Manohar Maria pan dan Nor Azlina Hasbullah (2013). The impact of physical module (adventure-based activity) of Ma laysia's National Service Training Programme on team cohesion. Joumal of PhysicalEducation and Sports Management.Vol. 4. Bil 3. August.hlm 36-43

${ }^{32}$ Lee, Ju Hee (2011). A Study on the Civilian Control of the Military Authorities Since Democratization Case Study: South Korea and Argentina. Social Science Research Review. Vol 27. Bil 3. September. hlm 53-75

${ }^{33}$ Abdul Rahman, A. A. (1997). Motivasi dan Pembangunan Diri. Kuala Lumpur: Utusan Publications. Baungartner. Hlm 9-42
} 
dan fizikal pelatih supaya lebih sabar dan cekal menjalani latihan yang mencabar kemampuan diri supaya jika berlaku sebarang bencana atau peperangan dalam negara, mereka akan berani untuk berjuang ${ }^{34}$. Jika di Britain dan Australia, pelatih diberi latihan separa ketenteraan supaya mereka bersedia untuk direkrut dalam pasukan ketenteraan selepas tamat latihan kerahan tenaga. Hal ini demikian kerana pada ketika itu mereka sedang bersedia untuk menghadapi peperangan. Selain itu, jika dilihat, latihan kerahan tenaga yang diamalkan oleh Malaysia, Australia dan Britain ini dapat melahirkan semangat patriotisme dan nasionalisme dalam diri pelatih ${ }^{35}$. Hal ini demikian kerana sepanjang tempoh latihan mereka didedahkan kepada aktiviti-aktiviti yang dapat memupuk rasa cintakan negara seperti nyanyian lagu kebanggaan negara, ceramah motivasi tentang negara dan sebagainya ${ }^{36}$.

\begin{abstract}
"Elemen asas yang perlu diberikan perhatian dalam usaha membina sebuah negara bangsa ialah pemupukan semangat patriotisme dan nasionalisme dalam kalangan seluruh rakyat tidak kira tua muda, kecil besar mahupun miskin atau kaya. Usaha ini memerlukan pendekatan menyeluruh supaya seluruh anggota masyarakat khususnya generasi baharu menghayati semangat ini dalam jiwa mereka dan membentuk jati diri yang utuh serta mantap. Semangat patriotisme dan nasionalisme ini umpama perisai bagi kedaulatan sesebuah negara ${ }^{37}$.
\end{abstract}

Semangat patriotisme ialah semangat berani dalam diri, berani untuk berkorban apa sahaja demi mempertahankan negara ${ }^{38}$. Manakala, nasionalisme ialah rasa cinta dan sayang yang tinggi terhadap negara dan menghargai setiap pencapaian negara ${ }^{39}$. Semangat patriotisme yang tinggi dalam diri pelatih amat penting kerana dengan semangat patriotisme itu akan membuatkan pelatih sanggup berkorban nyawa untuk mempertahankan martabat dan maruah negara ${ }^{40}$. Jika di Malaysia, semangat patriotisme dan nasionalisme dalam diri para pelatih dipupuk melalui pembelajaran 4 modul utama ${ }^{4}$. Dalam setiap modul, pelatih akan didedahkan tentang nilai-nilai murni dalam kehidupan dan kepentingan menyayangi dan melindungi negara. Pembelajaran 4 modul ini dilakukan pada waktu pagi sehingga tengah hari, manakala pada waktu petang pelatih akan menjalankan latihan kecergasan fizikal $^{42}$. Seterusnya, persamaan ciri dan perlaksanaan latihan kerahan tenaga untuk ketiga-tiga buah negara ini adalah mereka menyediakan fasiliti asas untuk setiap pelatih ${ }^{43}$. Fasiliti asas adalah seperti

\footnotetext{
${ }^{34}$ Jaffry Zakaria, Manohar Maria pan dan Nor Azlina Hasbullah (2013). The impact of physical module (adventure-based activity) of Ma laysia's National Service Training Programme on team cohesion. Joumal of PhysicalEducation and Sports Management.Vol.4. Bil 3. August. hlm 36-43

${ }^{35}$ negara sila rujuk Berns, W.(1997). “On Patriotism.” Public Interest, Spring, 1997. hlm 19.

${ }^{36}$ Hapsah Md Yusof, Nur Afifah Bahanum, Nurul Ain Mohd Daud, Norazani Ahmad \& Fauziah Mohd Saad (2018). Penglibatan Belia dalam Aktiviti Sukarelawan Malaysia. Malaysian Joumal Of Youth Studies Vol 18. Jun. hlm 81-92. Lihat juga Anon. (2012). JLKN perkenal modul smart solat bantu pelatih dalami ibadah. Sinar Harian, 13 September. Hlm 10

${ }^{37}$ Mohd Hairul Anuar Razak, Jayum A. Ja wan, Adlina Abd. Halim, Mohd Mahadee Ismail \& Siti Aishah Misri (2013). Penghayatan Dan Kesedaran Patriotisme Dalam Kalangan Pelatih Program Latihan Khidmat Negara. Malaysian Journal Of Youth Studies Vol 8. Jun. hlm 3

${ }^{38} \mathrm{Ku}$ Hasnita Ku Samsu dan Mohd Haizam Mohd Nor (2011). Kepentingan Pendidikan Patriotisme Terhadap Warganegara Malaysia (The Importance Of Patriotic Education For Malaysian Citizens) Jati, Vol.,16, December 2011. hlm 23-34

${ }^{39}$ Anon. (2012). JLKN perkenal modul smart solat bantu pelatih dalami ibadah. Sinar Harian, 13 September. Hlm 10

${ }^{40}$ Teks Rasmi Titah Duli Yang Maha Mulia Paduka Seri Sultan Perak Sultan Nazrin Muizzuddin Shah. Upacara Perbarisan Pentauliahan Pega wai Kadet Palapes Universiti Awam Ketiga Puluh Lima. 20 Ogos 2016. Universiti Malaya, Kuala Lumpur. hlm 1-8

${ }^{41}$ Abdul Rahman Abdul Aziz, Mohd. Sobhi Ishak, Malike Brahim \& Mohd. Ainuddin Iskandar Lee Abdullah. (2004). Penyelidikan program khidmat negara dari aspek gagasan kenegaraan. Laporan Penyelidikan. Sintok: Pusat Penyelidikan dan Perundingan, Universiti Utara Malaysia.

${ }^{42}$ Jaffry Zakaria, Manohar Maria pan dan Nor Azlina Hasbullah (2013). The impact of physical module (adventure-based activity) of Malaysia's National Service Training Programme on team cohesion. Joumal of PhysicalEducation and Sports Management.Vol. 4. Bil 3. August. hlm 36-43

${ }^{43}$ Abidah Ainah Binti Mohamed @ Jamat Dan Ahmad Esa (2014). Pengurusan Risiko Menerusi Rogram Khidmat Masyarakat : Sorotan Literatur. Intemational Seminar On Technical And Vocational Education 2014. Hlm 718-725
} 
tempat tinggal, makanan dan pakaian. Pelatih-pelatih yang menyertai latihan ini akan ditempatkan di suatu ruangan khas yang telah disediakan oleh pihak kerajaan. Pelatih akan tinggal di dalam bilik tersebut bersama-sama dengan pelatih-pelatih yang lain ${ }^{44}$. Dalam ruangan tersebut, mereka akan disediakan dengan tilam, bantal dan almari. Pelatih juga turut disediakan dengan makanan. Mereka akan disediakan dengan makanan yang berkhasiat dengan kuantiti yang tepat. Hal ini bertujuan untuk menjaga kesihatan dan kecerdasan fizikal dan mental pelatih ${ }^{45}$. Pelatih akan disediakan makanan untuk sarapan pagi, makan tengah hari, dan juga makan malam. Pelatih dikehendaki untuk menepati waktu makan yang telah dijadualkan oleh pusat latihan. Hal ini bertujuan untuk memupuk sikap disiplin dalam menepati masa dalam diri setiap pelatih ${ }^{46}$.

Sepanjang tempoh latihan, pelatih telah diberikan pakaian yang hendaklah dipakai sepanjang tempoh latihan. Hal ini bertujuan untuk mewujudkan keseragaman antara para pelatih dan mewujudkan semangat bersatu antara satu sama lain. Pelatih diberikan sepasang pakaian seragam berceloreng yang digunakan sepanjang latihan. Jika di Malaysia, pakaian seragam celoreng yang disediakan adalah berwarna biru manakala di Britain dan Australia berwarna hijau. Pakaian seragam celoreng ini merupakan pakaian rasmi di pusat latihan dan para pelatih hendaklah menghormatinya. Justeru, perlaksanaan kerahan tenaga di Malaysia dengan Britain dan Australia, jelas menunjukkan bahawa latihan kerahan tenaga ini amat menggalakkan penyertaan anak-anak muda supaya mereka dapat berkhidmat untuk kesejahteraan negara. Selain itu, secara tidak langsung latihan kerahan tenaga ini dapat memupuk semangat patriotisme dan nasionalisme dalam diri pelatih. Di Britain dan Australia, pelatih yang menyertai latihan kerahan tenaga telah berani untuk turut serta dalam peperangan demi mempertahankan maruah negara.

\section{Kesimpulan}

Idea mewujudkan PLKN tercetus apabila menteri serta rakyat menghadiri Kongres Patriotisme Negara pada November 2002. Program ini dicadangkan bagi menyediakan golongan belia untuk menghadapi pelbagai cabaran baru dari dalam dan luar negara. Secara tak langsung dapat menyediakan golongan muda terhadap pelbagai jenis perubahan seperti teknologi, globalisasi dan politik ${ }^{47}$. Antara sebab lain yang menyokong perlaksanaan PLKN adalah untuk menanam semangat kesukarelaan dalam kalangan belia ${ }^{48}$. Semangat kesukarelaan amat penting untuk rakyat Malaysia terutamanya kerana negara ini terdiri daripada pelbagai bangsa ${ }^{49}$. Pentingnya untuk memupuk sifat-sifat positif dalam diri belia adalah untuk mengelakkan sifat individualistik dan materialistik menerajui diri belia. Dengan adanya semangat kesukarelaan, belia terutamanya akan lebih bertanggungjawab sesama sendiri dan juga

\footnotetext{
${ }^{44}$ Anon. (2012). JLKN perkenal modul smart solat bantu pelath dalami ibadah. Sinar Harian, 13 September. Hlm 10

${ }^{45}$ Jaffry Zakaria, Manohar Maria pan dan Nor Azlina Hasbullah (2013). The impact of physical module (adventure-based activity) of Ma laysia's National Service Training Programme on team cohesion. Joumal of PhysicalEducation and Sports Management.Vol. 4. Bil 3. August. hlm 36-43

${ }^{46}$ Abdul Rahman Abdul Aziz, Mohd. Sobhi Ishak, Malike Brahim \& Mohd. Ainuddin Iskandar Lee Abdullah. (2004). Penyelidikan program khidmat negara dari aspek gagasan kenegaraan. Laporan Penyelidikan. Sintok: Pusat Penyelidikan dan Perundingan, Universiti Utara Malaysia.

${ }^{47}$ Y. X. Fang, Sarjit S. Gill \& A. T. Talib (2017).Political Participation of Minority Youth in Ma laysia. Malaysian Joumal Of Youth Studies Vol 16. Jun. hlm 117-128, lihat jga kepentingan politik kepada belia dalam kajian Syed Arabi Idid, Azrul Hisyam Wakichan, Ha rtini Wakichan \& Nur Hafizah Ahmad (2019). Pengundi Belia, Penggunaan Media \& Politik. Malaysian Journal Of Youth Studies. Edisi Khas Yours'18 Agenda Sosial Vol 3. hlm 29-44, lihat juga Husna Ahmad Dimyati \& Mohd Azul Mohamad Salleh (2019). Media Sosial dan Pemilihan Parti Politik dalam Kalangan Belia. Malaysian Journal Of Youth Studies. Edisi Khas Yours'18 Agenda Sosial Vol 2. hlm 130-150 dan kajian Ismi Arif Ismail, Mohd Mursyid Arshad, Jufitri Joha, Steven Eric Krauss And Dzuhailmi Dahalan (2019). Political Socia lization of Malaysian Youth: The Changing Political Landscape and The Way Forward Malaysian Journal of Youth Studies. Edisi Khas Yours'18 Agenda Sosial Vol3. Hlm 250-263

${ }^{48}$ Azizan Bahari. (1998). Modenisasi: Implikasi dan cabaran kepada belia. Dlm. Azimi Hamzah \& Turiman Suandi (eds.). Pengukuhan Sinergi Belia dan Negara: Agenda Agen Pembangunan Pewaris Negara. Serdang: Universiti Putra Malaysia. Hlm 21-43

${ }^{49}$ Alis Puteh.Language \& nation building. Petaling Ja ya: SIRD. 2006.hlm 13-42
} 
mereka yang berada disekeliling mereka ${ }^{50}$. Ini juga dapat menyatukan semua bangsa dengan sifat kebergantungan sesama sendiri. Menjadi antara aset terpenting negara menjadi keutamaan kerajaan untuk sama-sama membentuk belia yang mampu mengangkat taraf negara ke peringkat tertinggi dalam pelbagai bidang dan PLKN adalah antara salah satu permulaan. Objektif PLKN secara keseluruhannya mementingkan masa depan negara yang bakal berdepan pelbagai perubahan, kecil atau besar.

\section{Rujukan}

Abdul Rahman Abdul Aziz, Mohd. Sobhi Ishak, Malike Brahim \& Mohd. Ainuddin Iskandar Lee Abdullah. (2004). Penyelidikan program khidmat negara dari aspek gagasan kenegaraan. Laporan Penyelidikan. Sintok: Pusat Penyelidikan dan Perundingan, Universiti Utara Malaysia.

Abdul Rahman Embong. (2001). Negara bangsa: Proses dan perbahasan. Bangi: Penerbit Universiti Kebangsaan Malaysia.

Abidah Ainah Binti Mohamed @ Jamat Dan Ahmad Esa (2014). Pengurusan Risiko Menerusi Rogram Khidmat Masyarakat : Sorotan Literatur. International Seminar On Technical And Vocational Education, 718-725

Adam Roberts (1967). The Strategy ofCivilian Defence, Faber and Faber Ltd, London.

Alis Puteh (2006). Language \& nation building. Petaling Jaya: SIRD.

Anon. (2012). JLKN perkenal modul smart solat bantu pelatih dalami ibadah. Sinar Harian, 13 September. Hlm 10

Azizan Bahari. (1998). Modenisasi: Implikasi dan cabaran kepada belia. Dlm. Azimi Hamzah \& Turiman Suandi (eds.). Pengukuhan Sinergi Belia dan Negara: Agenda Agen Pembangunan Pewaris Negara. Serdang: Universiti Putra Malaysia, 21-43

B. Jalal (2016). Hubungan Tentera Dan Masyarakat: Pandangan Rakyat Terhadap Peranan Angkatan Tentera Malaysia. Jurnal Jabatan Kenegaraan, Kepemimpinan dan Ketamadunan, Universiti Pertahanan Nasional, 4(1), 19-30

Berns, W. (1997). On Patriotism. Public Interest, Spring.

Hapsah Md Yusof, Nur Afifah Baharum, Nurul Ain Mohd Daud, Norazani Ahmad \& Fauziah Mohd Saad (2018). Penglibatan Belia dalam Aktiviti Sukarelawan Malaysia. Malaysian Journal of Youth Studies, 18, 81-92.

Husna Ahmad Dimyati \& Mohd Azul Mohamad Salleh (2019). Media Sosial dan Pemilihan Parti Politik dalam Kalangan Belia. Malaysian Journal Of Youth Studies, 2, 130-150.

Ismi Arif Ismail, Mohd Mursyid Arshad, Jufitri Joha, Steven Eric Krauss And Dzuhailmi Dahalan (2019). Political Socialization of Malaysian Youth: The Changing Political Landscape and The Way Forward. Malaysian Journal Of Youth Studies, 3, 250-263.

Jaffry Zakaria, Manohar Mariapan dan Nor Azlina Hasbullah (2013). The impact of physical module (adventure-based activity) of Malaysia's National Service Training Programme on team cohesion. Journal of Physical Education and Sports Management, 4(3), 36-43

$\mathrm{Ku}$ Hasnita Ku Samsu dan Mohd Haizam Mohd Nor (2011). Kepentingan Pendidikan Patriotisme Terhadap Warganegara Malaysia. Jati, 16, 23-34

Lee, J. H. (2011). A Study on the Civilian Control of the Military Authorities Since Democratization Case Study: South Korea and Argentina. Social Science Research Review, 27(3), 53-75

Mohd Hairul Anuar Razak, Jayum A. Jawan, Adlina Abd. Halim, Mohd Mahadee Ismail \& Siti Aishah Misri (2013). Penghayatan Dan Kesedaran Patriotisme Dalam Kalangan Pelatih Program Latihan Khidmat Negara. Malaysian Journal Of Youth Studies, 8(3).

Mohd Nazeri Bin Noor (2008). Dasar Pertahanan Negara Malaysia: Satu Analisa Terhadap Persenjataan. Tesis.Universiti Malaya: Fakulti Sastera Dan Sains Sosial.

Mohd Nazeri Bin Noor (2008). Dasar Pertahanan Negara Malaysia: Satu Analisa Terhadap Persenjataan. Tesis. Universiti Malaya: Fakulti Sastera Dan Sains Sosial.

\footnotetext{
${ }^{50}$ Azizan Bahari. (1998). Modenisasi: Implikasi dan cabaran kepada belia. Dlm. Azimi Hamzah \& Turiman Suandi (eds.). Pengukuhan Sinergi Belia dan Negara: Agenda Agen Pembangunan Pewaris Negara. Serdang: Universiti Putra Malaysia. HIm 21-43
} 
Mohd Nooraimy Bin Musa (2009). Dasar Pertahanan Negara - Menganalisis Kemampuan Angkatan Tentera Malaysia Mendukung Dasar Tersebut Pada Era Globalisasi. Universiti Malaya: Fakulti Sastera Dan Sains Sosial.

Perutusan YB Tan Sri Dato' Hj. Muhyiddin Bin Hj. Mohd. Yassin, Menteri Dalam Negeri,Tan Sri Dato' Hj. Muhyiddin Bin Hj. Mohd. Yassin. Dasar Keselamatan dan Ketenteraman Awam. Kementerian Dalam Negeri.2019.hlm iv

Projek Jiwa Murni, Akrabkan kerajaan, Tentera dan Rakyat. Patriot. Bil 1. 2000.hlm 8

Siti Raba'ah Hamzah, Turiman Suandi \& Ismi Arif Ismail (2019). Pengaruh Aktiviti Sukarela Terhadap Tingkah Laku Sedentari Belia Institusi Pengajian Tinggi di Malaysia. Malaysian Journal Of Youth Studies, 1, 50-68

Siti Raba'ah Hamzah, Turiman Suandi \& Siti Nur Syuhada Musa (2019). Profil Kesukarelawanan Belia Malaysia. Malaysian Journal of Youth Studies, 19, 18-37.

Syed Arabi Idid, Azrul Hisyam Wakichan, Hartini Wakichan \& Nur Hafizah Ahmad (2019). Pengundi Belia, Penggunaan Media \& Politik. Malaysian Journal Of Youth Studies, 3, 29-44.

Syuhaimi Saad (2010). Kumpulan Kedua AW Kementerian Pertahanan dilancarkan. BTDM. Bil. 106. Januari.

Teks Rasmi Perintah Ulung Panglima Tentera Darat Ke-25, Jeneral Datuk Raja Mohamed Affandi Raja Mohamed Noor Panglima Tentera Darat. 19 Jun 2013.

Teks Rasmi Perutusan Hari Tentera Darat Ke-85 Oleh Panglima Tentera Darat Pada 1 Mac 2018.

Teks Rasmi Perutusan Hari Tentera Darat Ke-85 Oleh Panglima Tentera Darat Pada 1 Mac 2018. Hlm $1-8$.

Teks Rasmi Perutusan Hari Ulang Tahun Tentera Darat Ke-79 .Jeneral Datuk Haji Zulkifli Haji Zainal Abidin, Panglima Tentera Darat Pada 1 Mac 2012.

Teks Rasmi Titah Duli Yang Maha Mulia Paduka Seri Sultan Perak Sultan Nazrin Muizzuddin Shah. Upacara Perbarisan Pentauliahan Pegawai Kadet Palapes Universiti Awam Ketiga Puluh Lima. 20 Ogos 2016. Universiti Malaya, Kuala Lumpur.

Teks Rasmi Titah Duli Yang Maha Mulia Paduka Seri Sultan Perak Sultan Nazrin Muizzuddin Shah. Upacara Perbarisan Pentauliahan Pegawai Kadet Palapes Universiti Awam Ketiga Puluh Lima. 20 Ogos 2016. Universiti Malaya, Kuala Lumpur.

Teks Rasmi Ucapan Jeneral Tan Sri Dato' Sri Abdul Aziz Bin Hj Zainal, Panglima Angkatan Tentera Sempena Majlis Pelancaran Sambutan 25 Tahun Pernama Di Auditorium Kementerian Pertahanan Pada 20 Julai 2007.

Vishalache B. (2013). Penilaian PLKN Dari Perspektif Pelatih: Satu Kajian Kes. Asia Pacific Journal of Educators and Education, 28, 69-80.

Wan Kamarudin Wan Hamat (2002). Khidmat Bakti Ke Arah Mesra Rakyat. Patriot. Bil 2.

Y. X. Fang, Sarjit S. Gill \& A. T. Talib (2017).Political Participation of Minority Youth in Malaysia. Malaysian Journal Of Youth Studies Vol 16. Jun. hlm 117-128,

Yasmin Binti Yaccob \& Mohd Ibrani Shahrimin Adam Assim (2018). Kesepaduan Sosial Melalui Program Anugerah Remaja Perdana Rakan Muda. Malaysian Journal Of Youth Studies, 18, 219242. 